\title{
Generalist Teachers' Knowledge Level on Causes and Effects of Injuries in Schools' Sports
}

\author{
Ernest Tsikata $^{1^{*}}$, Abduli Fuseini ${ }^{2}$, Charlotte Adomah Diabor $^{3}$, Kweku Victory $^{4}$ \\ ${ }^{1}$ Department of Science, Offinso College of Education, Offinso, Ghana \\ ${ }^{2}$ Department of Science, Tamale College of Education, Tamale, Ghana \\ ${ }^{3}$ Department of Science, Komenda College of Education, Komenda, Ghana \\ ${ }^{4}$ Department of Science, Enchi College of Education, Enchi, Ghana \\ Email: bordohlity@yahoo.co.uk
}

Received: 02 November 2021; Revised: 14 December 2021; Accepted: 11 January 2022

\begin{abstract}
The Purpose of the Study was to examine the knowledge levels of generalist teachers' causes and effects of injuries in basic schools' sports in the Central Gonja District of Savannah Region, Ghana. The study employed a descriptive survey design. The population of this study comprised 190 generalist teachers from 95 schools in the Central Gonja District of Savannah Region. A total of 180 respondents and ninety (90) schools were sampled using cluster and simple random sampling techniques. A researcher-designed questionnaire titled "Fuzzy First Aid Assessment Inventory" was the main tool for the data collection for this study. The questionnaire consists of 20 items on knowledge on causes and effects of sports injuries. The participant had the option to Strongly Agree, Agree, Disagree, and Strongly Disagree for items. Quantitative primary data were analyzed using descriptive analysis of frequency counts and percentages, the mean and standard deviations. The study concluded that knowledge levels of generalist teachers on the causes of sports injury were low. It is recommended that Schools authorities should sensitize the generalist teachers through in-service training, workshops, seminars to appreciate the importance of having first aid knowledge not first aid boxes by name. The study also revealed that sports teachers' knowledge levels on the effects of sports injuries were high. It is also recommended that the universities and colleges of educations that train teachers should consider first aid a core subject not an elective, to have effective knowledge in the administering of basic first aid.
\end{abstract}

Keywords: teachers, knowledge, causes, effects, injuries, schools' sports

\section{Introduction}

Youngsters unsurprisingly are dynamic and adventurous, besides they have a high level of motor aggravation, as they continue to explore their environment which helps them to learn and acquire new knowledge quickly (Geetha, 2016). However, school children stand a higher risk of being injured due to the sensitive nature as well as some developmental characteristics. Students naturally engage in play as part of physical activities, which develop their cognitive, emotional, physical, and social competencies at their early stages of life. In their play process, these students stand a higher risk of being injured due to the sensitive nature as well as some developmental characteristics. The recent accident which claimed a total of 12 lives at Alipe near Yapie on the Buipe Tamale road in the Central Gonja District

Copyright (C2022 Ernest Tsikata, et al.

DOI: https://doi.org/10.37256/ser.3120221227

This is an open-access article distributed under a CC BY license

(Creative Commons Attribution 4.0 International License)

https://creativecommons.org/licenses/by/4.0/ 
was just a clear example of the rate at which emergencies occur in the district and why the need for first aid knowledge of the majority of the population in the district. At least the performance of Cardiopulmonary Recusation could mean a difference at some point in time (Ghana Business New, 2018). First aid knowledge of teachers is so essential because children fall ill and also, sustain injury almost every day in schools (UNICEF, 2021). Students come from different cultural backgrounds with different characters and health needs which placed them at a high risk of vulnerability to all kinds of emergencies that required teachers to possess the best knowledge to be able to act immediately and smoothly (Sumithra \& Dhanalakshmi, 2019). The Central Gonja District report from the police Motto Traffic and Transport Department revealed that between January and May 2021, a total of 131 different cases of injuries were recorded from schools, motorists and assault, and out of these, 34 lives were lost in the capital Buipe alone. Unfortunately, the researcher observed that most of the generalist teachers engage in first aid practices that raise a lot of questions about the knowledge levels on first aid practices in the schools. It was due to their lack of interest or motivation in first aid and the difficulty in administering first aid in the district. Generalist teachers applied hot Shea butter, kerosene, hydrogen peroxide, and Petrol directly on fresh wounds. Also, the insertion of fingers into children's throats when they are choked is some of the common practices among the teachers in the district. This approach has led to serious health complications for students-athletes in the district.

However, most of the studies conducted on first aid knowledge of teachers were all based in the western world mostly, qualitative with a larger sample size but did not take much consideration on the African perspective; hence, the current study examined knowledge levels of teachers in the basic schools in the Central Gonja District of the Savannah Region (De Buck et al., 2020; Gyedu et al., 2015; Engebretsen et al., 2012). In view of all these, the researcher aimed to investigate the levels of knowledge of the generalist teachers on causes, management and effects of injury in schools and suggest possible ways of improving the situation. The Purpose of the Study was to examine the knowledge levels of generalist teachers' causes and effects of injuries in basic schools' sports in the Central Gonja District of Savannah Region, Ghana. The study was guided by these research questions: (1) What is the knowledge level of generalist teachers on causes of injuries in schools' sports? (2) What is the knowledge level of generalist teachers on the effects of common sports injury in the Central Gonja District?

\section{Literature review}

Sports injuries are commonly defined as any physical harm sustained by a player resulting from a match or training. United States Injury Law and Legal Definition (2020) defines injury in a general term as harm suffered, by a person due to some act or omission done by another person, and can generally give rise to a civil tort claim or a criminal prosecution. This harm could be physical or emotional pain and suffering, damage to reputation or dignity, loss of a legal right, breach of contract, or damage to real or personal property.

\subsection{Causes of sports injury}

Shashidhara and Krinshnaswamy (2017) and Bhadwaj (2013) identified intrinsic and extrinsic factors as the two factors responsible for common sports injuries. To them, the extrinsic factors include Training-related factors, Equipment-related factors, Environmental factors, Psychological factors, and Nutritional factors. However, the intrinsic factors include individual difference factors. Kalaskar and Kalaskar (2016) conducted a study on the Knowledge and Attitude of the Sports Teachers in Central India towards causes of sports-related Oro-facial injuries and the use of Mouth Guard. Their findings indicated that the sports teachers possessed knowledge of first aid to Oro-facial injuries which depart from the current study. However, Amro and Qtait (2017) in their study on general knowledge and attitude of first aid among school teachers in Palestine among 150 school teachers from eight (8) schools concluded that the school teachers' knowledge of first aid concerning causes of injury was high which also depart from the current study. The current study equally departs from the early study by Kalav and Manisha (2019) who found that there was a good knowledge of teachers regarding first aid measures on common causes of injuries.

Training-related factors causing injuries in Sports are common in all disciplines. This factor concerns the kind of training athletes engage previously before competitions. Training programs are supposed to be designed in line with the exercise science principles, for instance, frequency, intensity, time, type, overload, and age-related (Shashidhara \& 
Krinshnaswamy, 2017). Unfortunately, most training programs lack these requirements (Bhardwaj, 2013). Practically, a sudden increase in frequency, intensity, and duration, or simply changing training methods can go beyond the tissue's tolerance level leading to increased risk of injury (Kalav \& Manisha, 2019). Performing sport activities procedures poorly can put excessive stress on tissues, hence inflicting damage to the stressing tissues which subsequently results in an injury (Bhadwaj, 2013).

The kind of tools or equipment used for the execution of an activity in sports (Mears et al., 2018). Sports participation involves the use of facilities and equipment and each equipment depends on the type of discipline required. Using the wrong equipment intentionally or unintentionally may present certain drawbacks in the form of injury in the execution of an activity (Mears et al., 2018). Any type of equipment used in the execution of any activity should match the kind of activity concerning size and weight (Mears et al., 2018). Most injuries are caused by not the mere negligence of the players nor the equipment fault according to Henrich's theory of injury causation, but the type of environment athletes finds themselves in during the performance of particular sports or exercise during a competition (Valent et al., 2004). Valent et al. (2004) point out that before lessons and activities begin, teachers should pay attention to the weather and environmental conditions to decide whether the activities should be held as scheduled or not. Mears et al. (2018) affirmed that teachers should arrange a safe and adequately spaced venue for students to participate in physical activities that involve a large crowd. Mears et al. (2018) went on to add that a protective device must be installed over glass windows and doors lights, pillars, fans, and sharp edges, which are in close vicinity to the activity area.

Besides physical factors, there are psychological factors that could lead to serious injuries (WHO, 2014). These factors may include stress and certain predisposing attitudes of athletes that could contribute to injuries in a game setting. WHO (2014) explained psychological and emotional factors as the state of mind of an individual about the performance of any activity. When participating in a game either in a match or training, full concentration is needed in other to avoid unwarranted injury, since this factor comes as a result of an athlete's performing for a long time with fatigue which could be stressful and emotionally challenging (Azizoddin et al., 2019; WHO, 2014). Naturally, muscle fibers need a lot of nutrients in other to fuel the system to be able to carry out the necessary motor activities (Soligard et al., 2016; Engebretsen et al., 2013). It was also added that all these therapies in their rightful proportion will subsequently prevent hypernatremia (Sundberg et al., 2011). Having good fluid intake helps the athletes by reducing the rate of overheating and preventing heatstroke. When an athlete lacks the correct protein intake, it may cause the soft tissue not to recover and adapt properly (Sundberg et al., 2011). It can lead to Delay-onset muscle soreness (DOMS) and overtraining syndrome. Most often sports injuries result from several factors which may include both internal and external reasons. The main nutritional factors that could lead to athletes' injury are lack of protein and balanced diet from the various literature.

\subsection{Effects of common sports injuries}

Injuries constitute the leading causes of death and disability in the lowest and middle-income countries. Major health problems globally, especially in countries that have over the years experienced increased industrialization and motorization (Engebretsen et al., 2012). Countries like East Asia and Latin America are the worse of the sufferers. In some of the low and middle-income countries, for instance, South Asia and Africa, injury constitutes the leading cause of adult mortality and disabilities, most of the injuries are as result of accidents, from both occupational and sports (Giampaolo \& Luca, 2013). According to Engebretsen et al. (2012), sports injury definition is fraught with many different views from different scholars and these differences could make the imperial results of any study too difficult to conclude. They also stated that school sports injuries account for almost half of the injuries in secondary schools' sports. As children participate in games and other sporting activities in school sometimes, they involve in accidents of all kinds (Geetha, 2016). Injury amongst sports teams causes significant disruptions to the school and sports first aid (Sumithra \& Dhanalakshmi, 2019).

According to Maffulli et al. (2009), little is known about the role that sleep deprivation plays in the risk of injuries in adolescent athletes. Modest sleep loss has been associated with the impairment of psychomotor performance in adults, however, little is known about the effects in children (Maffulli et al., 2009). Athletic performance generally is affected by sleep patterns, and sleep deprivation is known to dampen reaction time and affect mood and cognitive functions, which could increase the risk of injury in adolescent athletes (Mahure et al., 2018). Abernethy and MacAuley (2003) suggested that sports injury causes severe effects on both the athletes and their families, hence the need for a 
medical specialist to find strategies to combat long time effects of injuries on schools' athletes and this equally reflects an adverse effect on the nation's economy as well as ending up of one's future career. The impact of sports injury has become a dynamic phenomenon in the lives of athletes worldwide (Caine \& Maffulli, 2005). Injury generally can place some kind of effects on the athlete's personal development and progress in life, physically, socioeconomically, psychologically, mentally and emotionally challenges to the injured athletes (Caine \& Maffulli, 2005). According to the Grief process Model of injury, this would base on the idea that injured athletes would feel they had lost some aspect of their 'self', which is lucky to be related to negative thoughts and beliefs of such athletes.

The Grief Model of injury uses the Kuhbler-Ross Model of Bereavement (from the 1969 book on death and dying) to explain the effects of loss of 'self'. The model uses five stages to express when someone is dealing with loss; first is disbelief and denial, anger, bargaining, depression and, acceptance and resignation. In one way or the other, an athlete may experience any of the stages when recovering from an injury. The advantage of a grief process model of injury is that it helps the athlete and practitioners to understand the process of change and the challenge of coping, without presuming psychopathology (Podlog et al., 2014).

The Model, according to Podlog et al. (2014), relates the understanding to the 'Cognitive Appraisal Model of Psychological Adjustment from Athletic Injury' (CAMPAAI). They argued that an athlete's response to injury is dependent upon the cognitive appraisal of their condition and would have to assess and evaluate the stress of the injury as well as the severity and this is only based on these cognitive appraisals that will determine the athletes' emotional response to such situation or conditions. For example, an athlete's fear of having regenerated injury may lead to anger and depression; studies, such as Ivarsson and Johnson (2010), suggested that this fearful emotional response can in turn affect the behavior that athletes show, such as their adherence to a rehabilitation program, leading to an increase in delay in recovery time.

\section{Materials and methods}

The study employed a descriptive survey design. The population of this study comprised 190 generalist teachers from 95 schools in the Central Gonja District of Savannah Region. Cluster and simple random sampling techniques were used for the study. A total of 180 respondents were sampled using cluster and simple random sampling techniques. In the first stage, the cluster sampling technique was employed for the selection of the ninety (90) schools. The cluster sampling technique is ideal when the population of interest lies within surrounding communities that are not far from reach (Sharma, 2017). The second stage employed the simple random sampling technique to select one hundred and eighty (180) respondents for the study. The selected sample included two (2) generalist teachers from each of the 33 junior high schools, and 57 primary schools respectively. A researcher-designed questionnaire titled "Fuzzy First Aid Assessment Inventory" was the main tool for the data collection for this study. The questionnaire consists of 20 items on knowledge on causes and effects of sports injuries. The participant had the option to Strongly Agree, Agree, Disagree, and Strongly Disagree for items. Quantitative primary data were analyzed using descriptive analysis of frequency counts and percentages, the mean and standard deviations.

In this study, content validity was established through the review of the instrument by the researcher's supervisor who is familiar with the constructs being measured and later submitted to senior lecturers handling Statistics for clarity of language and for interpreting the meaning behind the questions. The questionnaire was revised based on the comments and suggestions of these experts. For example, under section two of the instrument, the items were initially ambiguous and poorly constructed but it was later modified to increase content validity. A pilot study was conducted among selected teachers in Damongo and Daboya who shared similar geographical characteristics. After obtaining permission from the schools' headmasters via the district director of education. Reliability of a study instrument is the degree of a study instrument such as a questionnaire, or an interview guide to measuring a subject or a variable on different occasions and all occasions consistently producing similar results. The reliability of the scores of the instrument was calculated at $r=0.77$ using Cronbach's alpha model. This figure indicates good internal consistency as reliability coefficients of approximately .60 or greater are considered adequate. 


\section{Results}

\subsection{Knowledge level of generalist teachers on causes of injuries in schools' sports}

The results in Table 1 revealed that generalist teachers in this study generally exhibited an average knowledge level towards the common causes of injury in first aid at schools. The results indicated a total mean of $\mathrm{M}=30.3$, an average mean and a standard deviation score of Mean $=3.17 \pm \mathrm{SD}=0.92$. This implies that generalist teachers need more knowledge on the common causes of sports injury in the schools at Central Gonja District of the Savannah Region.

Table 1. Means and standard deviation showing sports teachers' knowledge on causes of injury

\begin{tabular}{|c|c|c|c|c|}
\hline & Causes of injury items & $\mathrm{N}$ & Mean & $\mathrm{SD}$ \\
\hline \multirow{10}{*}{$\begin{array}{c}\text { Average of Mean }=3.17 \\
\mathrm{SD}=0.92\end{array}$} & Fatigue and overuse during competition and training. & 180 & 3.60 & 0.72 \\
\hline & Not playing to the rules of the competition or recklessness. & 180 & 3.37 & 0.89 \\
\hline & Poor training methods and technique. & 180 & 3.21 & 0.95 \\
\hline & Overtraining loads. & 180 & 2.90 & 0.91 \\
\hline & Insufficient or poor fitness. & 180 & 2.80 & 0.99 \\
\hline & Unsafe exercising environments. & 180 & 3.20 & 0.98 \\
\hline & Lack of concentration and attention. & 180 & 2.99 & 0.98 \\
\hline & Improper balance diet and dehydration & 180 & 2.51 & 0.94 \\
\hline & Inadequate warm-up. & 180 & 2.89 & 0.97 \\
\hline & Using of wrong costume, body contact, and equipment & 180 & 2.83 & 0.97 \\
\hline
\end{tabular}

Key: $\mathrm{SA}=4, \mathrm{~A}=3, \mathrm{D}=2, \mathrm{SD}=1$

Source: Field Survey, 2019

\subsection{Knowledge level of generalist teachers on the effects of common sports injury}

Table 2: Results show that generalist teachers generally exhibited High knowledge levels on the effects of the injury on athletes in the school's sports. The results indicated a total mean of $\mathrm{M}=35.5$ and an average mean and a standard deviation score of Mean $=3.6 \pm \mathrm{SD}=0.62$. This implies that there is a presence of knowledge as far as effects of injury are concerned. 
Table 2. Means and standard deviation showing respondents' knowledge on the effects of sports injury

\begin{tabular}{|c|c|c|c|c|}
\hline & Effects of sports injury items & $\mathrm{N}$ & Mean & SD \\
\hline & Depression, anxiety, physical pains and emotional problems. & 180 & 3.49 & 0.74 \\
\hline & Temporary or permanent disability, sometimes leads to amputations and death. & 180 & 3.64 & 0.63 \\
\hline & Financial responsibility on families and teams/schools. & 180 & 3.63 & 0.63 \\
\hline & Athletes drop from competitions on both short-term and long-term bases. & 180 & 3.64 & 0.57 \\
\hline Average of Mean $=3.60$ & Parents, the schools as well as the government are equally affected. & 180 & 3.51 & 0.54 \\
\hline \multirow[t]{5}{*}{$\mathrm{SD}=0.62$} & Athletes stop schooling because of injury. & 180 & 3.52 & 0.56 \\
\hline & Some athlete dies from the injury. & 180 & 3.54 & 0.55 \\
\hline & Parents discourage athletes because of the reoccurrence of injuries. & 180 & 3.45 & 0.63 \\
\hline & Athletes' academic performance in school suffers due to injury effects. & 180 & 3.57 & 0.61 \\
\hline & Athletes develop fear for future sports because of injury. & 180 & 3.53 & 0.66 \\
\hline
\end{tabular}

Key, $\mathrm{SA}=4, \mathrm{~A}=3, \mathrm{D}=2, \mathrm{SD}=1$

Source: Field Survey, 2019

\section{Discussion}

This section sought to examine the levels of knowledge of generalist teachers regarding first aid management in schools of Central Gonja District of Ghana. The research design used in the study was descriptive. Generalist teachers also demonstrated fair knowledge levels on the management of sports injury with the mean score of Mean $=2.9 \pm \mathrm{SD}$ $=0.90$. Generally, the results indicate inadequate knowledge level regarding injury management in the school first aid, which sends a strong signal to how first aid in the schools has not been given the needed attention in the district. Knowing what to do during an emergency is key to health promotion and improves general health and wellbeing of school children in the school environment, however, teachers' knowledge in basic first aid in the form of injury management in schools is limited in the district. This may be a result of lack of education, equipment, awareness, and the lack of interest resulting from insufficient motivation and encouragement from educational authorities and government. This implies that generalist teachers had average knowledge on the common causes of sports injury in the schools in the Central Gonja District of the Savannah Region, and this study is in line with Awad et al. (2017), in their study to assess elementary school teachers' level of knowledge and attitude regarding causes of traumatic dental injuries and found that knowledge about causes of tooth avulsion was inadequate. However, findings from this current study did not reaffirm from an earlier study conducted by Kalav and Manisha (2019) on the assessment of knowledge regarding first aid measures for common causes of injuries in children among school teachers of Saveetha in India, concluded that there was a good knowledge of teachers regarding first aid measures on common causes of injuries.

This part of the study presents a discussion on the results of research question two. The levels of knowledge on effects of injury saw good scores with mean scores Mean $=3.6 \pm \mathrm{SD}=0.62$. These results indicate that generalist teachers' exhibited good knowledge regarding the effects that injuries can have on athletes. This means that since they cannot identify what causes injury and have a challenge as to how injuries have been managed or treated it indicates that they are following the principle of "prevention is better than cure" and this is also understood better with the Grief Model of injury effects to athletes. It implies that the effects of physical injuries are not strange and they may come in various forms, economic, psychological, and emotional. This might be because the deaths recorded during motor 
accidents, gas explosions, water accidents, stadium disasters, and COVID-19 pandemic were still fresh in the minds of sports teachers so they were able to respond confidently and successfully. Results corroborate Öztürk and Kılıç (2013) who conducted a study on the effects of injury rate and socioeconomic costs resulting from sports injuries in Flanders. Research on the burden of sports injury on a nation's budget showed that the total direct medical cost generalized for the participants of the Flemish sport was 15,027,423 Euros, which amounted to $0.07 \%$ to $0.08 \%$ of the total budget spent on healthcare which supported the current study (Öztürk \& Kılıç, 2013).

\section{Conclusion}

Based on the findings of the study, it was concluded that knowledge levels of generalist teachers on the causes of sports injury were low. This was strongly supported by the Domino theory of accident causation when it was stated that lack of knowledge of first aid and causes of injury were the factors leading to many accidents in construction industries. This situation is not different in the various schools, especially during sports and exercise. It is recommended that Schools authorities should sensitize the generalist teachers through in-service training, workshops, seminars to appreciate the importance of having first aid knowledge, not first aid boxes by name. This can be possible through effective collaboration with the health directorate to institute sick bays in the schools. However, findings show that sports teachers' knowledge levels on the effects of sports injuries were high. From the Grief model of injury, effect on athlete's awareness of the cause of a problem is a one-way step to get the problem solved but, the effect of injuries is severe on the emotional state of athletes as it cannot easily be inferred during the copping stage of the rehabilitation from the victim. It is also recommended that the universities and colleges of educations that train teachers should consider first aid a core subject, not an elective, as is the case in the colleges of educations so as for all teachers to have effective knowledge in the administering of basic first aid.

\section{Conflict of interest}

The authors declare no conflict of interest. No funders had any role in the design of the study; in the collection, analyses, or interpretation of data; in the writing of the manuscript, or in the decision to publish the results.

\section{Acknowledgments}

We acknowledge Dr. Anthony Bordoh for his input and suggestions.

\section{References}

Abernethy, L., \& MacAuley, D. (2003). Impact of school sports injury (short report). British Journal of Sports Medecine, 37(4), 354-355. http://dx.doi.org/10.1136/bjsm.37.4.354

Amro, N. R., \& Qtait, M. (2017). General knowledge \& attitude of first aid among schoolteacher's in Palestine. International Journal of Innovative Research in Medical Science (IJIRMS), 2(4), 660-665. https://doi.org/10.23958/ ijirms/vol02-i04/05

Awad, M. A, AlHammadi, E., Malalla, M., Maklai, Z., Tariq, A., Al-Ali, B., Al Jameel, A., \& El Batawi, H. (2017). Assessment of elementary school teachers' level of knowledge and attitude regarding traumatic dental injuries in the United Arab Emirates. International Journal of Dentistry, 2017(2), 1-7. https://doi.org/10.1155/2017/1025324

Azizoddin, D. R., Jolly, M., Arora, S., Yelin, E., \& Katz, P. (2019). Longitudinal study of fatigue, stress, and depression: Role of reduction in stress toward improvement in fatigue. Arthritis Care and Research, 72(10), 14401448. https://doi.org/10.1002/acr.24052

Bhardwaj, S. (2013). Common sports injuries and their management. International Journal of Informative and Futuristic Research (IJIFR), 1(3), 46-55.

Caine, D. J., \& Maffulli, N. (2005). Epidemiology of pediatric sports injuries: Individual sports. Karger AG, Basel. 
De Buck, E., Laermans, J., Vanhove, A. C., Dockx, K., Vandekerckhove, P., \& Geduld, H. (2020). An educational pathway and teaching materials for first aid training of children in sub-Saharan Africa based on the best available evidence. BMC Public Health, 20, 836. https://doi.org/10.1186/s12889-020-08857-5

Engebretsen, L., Soligard, T., Steffen, K., Alonso, J. M., Aubry, M., Budgett, R., Dvorak, J., Jegathesan, M., Meeuwisse, W. H., Mountjoy, M., Palmer-Green, D., Vanhegan, I., \& Renström, P. A. (2013). Sports injuries and illnesses during the London Summer Olympic Games 2012. British Journal of Sports Medicine, 47(7), 407-414. https://doi.org/10.1136/bjsports-2013-092380

Geetha, C. (2016). Knowledge on selected first aid measures among school children, Puducherry. International Journal of Applied Research, 2(2), 504-506.

Ghana Business New. (2018, July 29). St John Ambulance-Ghana calls for legislation of first aid. Retrieved on Friday 27th August 2021. https://www.ghanabusinessnews.com/2018/07/30/st-john-ambulance-ghana-calls-forlegislation-of-first-aid/

Giampaolo, S., \& Luca, P. (2013). Psychology of sport injury rehabilitation: a review of models and interventions. Journal of Human Sport and Exercise, 8(4), 1029-1044. https://doi.org/10.4100/jhse.2013.84.13

Gyedu, A., Mock, C., Nakua, E., Otupiri, E., Donkor, P. A., \& Ebe, B. E. (2015). Pediatric first aid practices in Ghana: A population-based survey. World Journal of Surgery, 39(8), 1859-1866. https://doi.org/10.1007/s00268-015-30611

Ivarsson, A. \& Johnson, U. (2010). Psychological factors as predictors of injury among senior soccer players. A prospective study. Journal of Sports Science \& Medicine, 9(2), 347-352. https://pubmed.ncbi.nlm.nih. gov/24149706/

Kalaskar, A. R., \& Kalaskar, R. (2016). Knowledge and attitude of the sports teachers in central India towards orofacial injuries and the use of mouth guard. Journal of Sports Medicine \& Doping Studies, 6(3). https://doi. org/10.4172/2161-0673.1000179

Kalav, B. S., \& Manisha, R. (2019). Assessment of knowledge regarding first aid measures for common injuries in children among school teachers. Indian Journal of Applied Research, 9(8), 1-2.

Maffulli, N., Longo, G. U., Gougoulias, N., Loppini, M., \& Denaro, V. (2009). Long-term health outcomes of youth sports injuries. British Journal of Sports Medicine, 44(1), 21-25. https://doi.org/10.1136/bjsm.2009.069526

Mahure, S. A., Mollon, B., Capogna, B. M., Zuckerman, J. D., Kwon, Y. W., \& Rokito, A. S. (2018). Risk factors for recurrent instability or revision surgery following arthroscopic Bankart repair. The Bone and Joint Journal, 100B(3), 324-330. https://doi.org/10.1302/0301-620X.100B3.BJJ-2017-0557.R1

Mears, A. C., Osei-Owusu, P., Harland, A. R., Owen, A., \& Roberts, J. R. (2018). Perceived links between playing surfaces and injury: A worldwide study of elite association football players. Journal of Sports Medicine-Open, 4, 40. https://doi.org/10.1186/s40798-018-0155-y

Öztürk, S., \& Kılıç, D. (2013). What is the economic burden of sports injury? Joint Diseases \& Related Surgery, 24(2), 108-111. https://doi.org/10.5606/ehc.2013.24

Podlog, L., Heil, J., \& Schulte, S. (2014). Psychological factors in sports injury rehabilitation and return to play. Physical Medicine and Rehabilitation Clinics of North America, 25(4), 915-930. https://doi.org/10.1016/ j.pmr.2014.06.011

Sharma, G. (2017). Pros and cons of different sampling techniques. International Journal of Applied Science, 3(7), 749752. https://www.allresearchjournal.com/archives/2017/vol3issue7/PartK/3-7-69-542.pdf

Shashidhara, \& Krinshnaswamy P. C. (2017). Common sports injuries in athletics. International Journal of Physical Education, Sports and Health, 4(5), 20-21. https://www.kheljournal.com/archives/2017/vol4issue5/ PartA/4-4-33-365.pdf

Soligard, T., Steffen, K., Palmer, D., Alonso, J. M., Bahr, R., Lopes, A. D., Dvorak, J., Grant, M.-E., Meeuwisse, W., Mountjoy, M., Costa, L. O. P., Salmina, N., Budgett, R., \& Engebretsen, L. (2016). Sports injury and illness incidence in the Rio de Janeiro Olympic Summer Games: A prospective study of 11274 athletes from 207 countries. British Journal of Sports Medicine, 51(17), 1265-1271. http://dx.doi.org/10.1136/bjsports-2017-097956

Sumithra, M., \& Dhanalakshmi, N. (2019). Effectiveness of programmed teaching on levels of knowledge and expressed practices regarding first aid management among primary school teachers. International Journal of Advances in Nursing Management, 7(1), 9-12. https://doi.org/10.5958/2454-2652.2019.00003.9

Sundberg, J., Estrada, C., Jenkins, C., Ray, J., \& Abramo, T. (2011). Hypothermia is associated with poor outcome in pediatric trauma patients. The American Journal of Emergency Medicine, 29(9), 1019-1022. https://doi. org/10.1016/j.ajem.2010.06.002

UNICEF. (2021). Child and adolescent injuries. Retrieved Monday 25 may 2021. https://www.unicef.org/health/injuries United States Injury Law and Legal Definition. (2020). Legal information institute. https://www.law.cornell.edu/wex 
Valent, F., Little, D., Bertollini, R., Nemer, L. E., Barbone, F., \& Tamburlini, G. (2004). Burden of disease attributable to selected environmental factors and injury among children and adolescents in Europe. The Lancet, 363(9426), 2032-2039. https://doi.org/10.1016/S0140-6736(04)16452-0

WHO. (2014). Injuries and violence the facts 2014. https://apps.who.int/iris/bitstream/handle/10665/149798/ 9789241508018_eng.pdf 